\title{
Pollen source areas of lakes with inflowing rivers: modern pollen influx data from Lake Baiyangdian, China
}

\author{
Qinghai Xu ${ }^{\mathrm{a}, \mathrm{b}, *}$, Fang Tian ${ }^{\mathrm{a}}$, M. Jane Bunting ${ }^{\mathrm{c}}$, Yuecong $\mathrm{Li}^{\mathrm{a}}$, Wei Ding ${ }^{\mathrm{a}}$, Xianyong Cao ${ }^{\mathrm{a}}$, Zhiguo He ${ }^{\mathrm{a}}$ \\ ${ }^{a}$ College of Resources and Environment Science, and Hebei Key Laboratory of Environmental Change and Ecological Construction, Hebei Normal University, \\ East Road of Southern 2nd Ring, Shijiazhuang 050024, China \\ ${ }^{\mathrm{b}}$ National Key Laboratory of Western China's Environmental System, Ministry of Education, Lanzhou University, Southern Tianshui Road, Lanzhou 730000, China \\ ${ }^{\mathrm{c}}$ Department of Geography, University of Hull, Cottingham Road, Hull HU6 7RX, UK
}

\section{A R T I C L E I N F O}

\section{Article history:}

Received 30 April 2011

Received in revised form

15 January 2012

Accepted 19 January 2012

Available online 17 February 2012

\section{Keywords:}

Pollen assemblages

Pollen influx

Relevant source area of pollen

Tauber trap

\begin{abstract}
A B S T R A C T
Comparing pollen influx recorded in traps above the surface and below the surface of Lake Baiyangdian in northern China shows that the average pollen influx in the traps above the surface is much lower, at 1210 grains $\mathrm{cm}^{-2} \mathrm{a}^{-1}$ (varying from 550 to 2770 grains $\mathrm{cm}^{-2} \mathrm{a}^{-1}$ ), than in the traps below the surface which average 8990 grains $\mathrm{cm}^{-2} \mathrm{a}^{-1}$ (ranging from 430 to 22310 grains $\mathrm{cm}^{-2} \mathrm{a}^{-1}$ ). This suggests that about $12 \%$ of the total pollen influx is transported by air, and $88 \%$ via inflowing water. If hydrophyte pollen types are not included, the mean pollen influx in the traps above the surface decreases to 470 grains $\mathrm{cm}^{-2} \mathrm{a}^{-1}$ (varying from 170 to 910 grains $\mathrm{cm}^{-2} \mathrm{a}^{-1}$ ) and to 5470 grains $\mathrm{cm}^{-2} \mathrm{a}^{-1}$ in the traps below the surface (ranging from 270 to 12820 grains $\mathrm{cm}^{-2} \mathrm{a}^{-1}$ ), suggesting that the contribution of waterborne pollen to the non-hydrophyte pollen assemblages in Lake Baiyangdian is about $92 \%$. When trap assemblages are compared with sediment-water interface samples from the same location, the differences between pollen assemblages collected using different methods are more significant than differences between assemblages collected at different sample sites in the lake using the same trapping methods. We compare the ratios of terrestrial pollen and aquicolous pollen types (T/A) between traps in the water and aerial traps, and examine pollen assemblages to determine whether proportions of long-distance taxa (i.e. those known to only grow beyond the estimated aerial source radius); these data suggest that the pollen source area of this lake is composed of three parts, an aerial component mainly carried by wind, a fluvial catchment component transported by rivers and another waterborne component transported by surface wash. Where the overall vegetation composition within the 'aerial catchment' is different from that of the hydrological catchment, the ratio between aerial and waterborne pollen influx offers a method for estimating the relative importance of these two sources, and therefore a starting point for defining a pollen source area for a lake with inflowing rivers.
\end{abstract}

(c) 2012 Elsevier Ltd. All rights reserved.

\section{Introduction}

Lacustrine pollen is an important proxy for reconstructing paleovegetation and paleoclimate, because pollen grains are usually well preserved in lake sediments (Sun and Wu, 1987; Gasse et al., 1991; Chen et al., 2006). Interpretation of the pollen signal and reconstruction of palaeovegetation is underpinned by assumptions about the spatial area reflected by the pollen signal and the taphonomy of different pollen types.

\footnotetext{
* Corresponding author. College of Resources and Environment Science, and Hebei Key Laboratory of Environmental Change and Ecological Construction, Hebei Normal University, East Road of Southern 2nd Ring, Shijiazhuang 050024, China. Tel.: +86 31180787621.

E-mail address: xuqinghai@mail.hebtu.edu.cn (Q. Xu).
}

About thirty years ago, palynological researchers began to produce quantitative estimates of a pollen source area for basins of different sizes (Jacobson and Bradshaw, 1981). The Prentice model of pollen dispersal and deposition (Prentice, 1985) allowed simulation of aerial pollen taphonomy to be used to estimate quantitative source areas for individual pollen types (Prentice et al., 1987), defined as the radius around the basin from which a defined percentage of the pollen type originated. Sugita modified this taphonomic model to incorporate mixing of pollen across a lake surface, and defined a pollen source area for the whole pollen assemblage, the Relevant Source Area of Pollen or RSAP (Sugita, 1993, 1994). The RSAP is defined in terms of the Extended R-value approach, an iterative means of estimating the parameters of the pollen dispersal and deposition model from empirical data (Parsons and Prentice, 1981; Prentice and Parsons, 1983). Where 
vegetation data are available from multiple radii around the basin, the distance at which adding further vegetation data to the analysis leads to no improvement in the likelihood function score (a measure of goodness of fit between the fitted model parameters and the empirical data) is defined as the RSAP for the whole assemblage being studied. The Prentice-Sugita model of pollen dispersal and deposition is currently being used as the primary basis for various approaches to the quantitative reconstruction of past vegetation composition and abundance such as the Landscape Reconstruction Algorithm (Sugita, 2007a, b) and the Multiple Scenario Approach (Bunting and Middleton, 2009). Sugita (1994) explores the implications in terms of RSAP for lakes of different sizes, and demonstrates that large lakes (typically $>500$ ha in area) record regional vegetation as if it is homogenous, with no variations in response to the spatial organization of that vegetation. The REVEALS approach software (Sugita, 2007a; Hellman et al., 2008) uses this property to reconstruct vegetation for a region $100-200 \mathrm{~km}$ in radius around such large lakes, but assumes that aerial transport of pollen to the sampled basin is the main taphonomic route.

Most lakes have inflowing rivers, so waterborne pollen may also make a substantial contribution to the pollen influx to the lake (McAndrews and Power, 1973; Peck, 1973, 1974; Bonny, 1978; Sun and Wu, 1987; Traverse, 1992; Huang et al., 2004; Xu et al., 2005; Brown et al., 2007). In order to attempt quantitative reconstructions of past vegetation and paleoclimate from the sedimentary record in such lakes, it is important to understand the relative importance of the different components of the pollen taphonomy and to characterize the spatial sensitivity of the record, the pollen source area.

Some empirical studies of pollen transport in rivers have been reported (e.g. Brush and Brush, 1972; Fall, 1981; Solomon et al., 1982). Flume experiments suggest that pollen grains will settle out into sediment when the water speed is lower than $0.3 \mathrm{~m} / \mathrm{s}$, and therefore that grains can remain in suspension and be transported long distance when the water speed is higher than $0.3 \mathrm{~m} / \mathrm{s}$ (Brush and Brush, 1972). Pollen assemblages from the Yellow River and Luan River follow these trends (Xu et al., 1994, 1995, 1996).

In this paper, we present an empirical study of the airborne and waterborne pollen components which compares the pollen influxes of traps above and below the lake surface with samples from the upper layer of the water-sediment interface within the lake in order to investigate the possible pollen source area and pollen deposition dynamics of a lake with substantial inflows, Lake Baiyangdian in the North China Plain.

\section{Study area}

Lake Baiyangdian is the largest fresh water lake in the North China Plain (Fig. 1). It is located in Anxin County of Hebei Province $\left(115^{\circ} 53^{\prime} 8.25^{\prime \prime}-116^{\circ} 6^{\prime} 9.64^{\prime \prime} \mathrm{E}, 38^{\circ} 47^{\prime} 1.69^{\prime \prime}-38^{\circ} 59^{\prime} 22.78^{\prime \prime} \mathrm{N}\right)$ and has a water area of $366 \mathrm{~km}^{2}$ and maximum water depth of $5 \mathrm{~m} \mathrm{(Xu}$ et al., 1988; Wang and Su, 2008). The lake has seven major inflowing rivers, the Baigou River (the longest at $275 \mathrm{~km}$ ), Zhulong River, Tang River, Cao River, Xiaoyi River, Pu River and Fu River (the shortest at $62 \mathrm{~km}$ ), which all originate in the Taihang Mountains

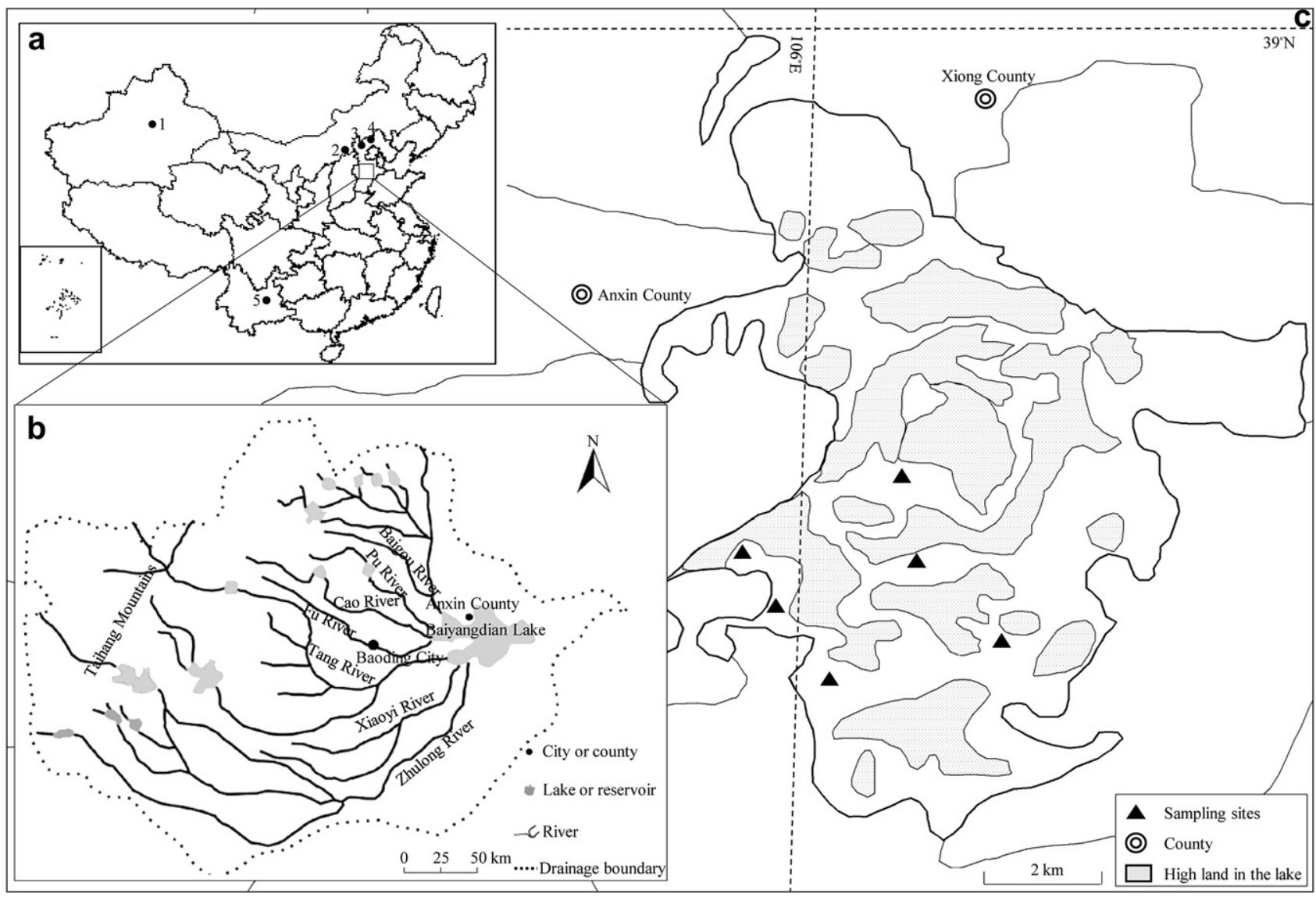

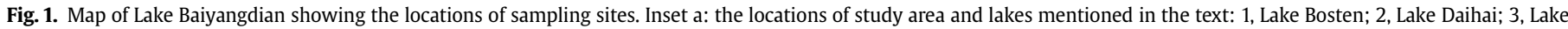

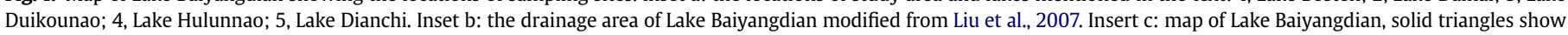
the trap sites. 
(Fig. 1). The catchment of Lake Baiyangdian is about $31199 \mathrm{~km}^{2}$ and drains about $34.46 \times 10^{8} \mathrm{~m}^{3}$ of water annually; about one third of this volume of water actually enters the lake every year (Hebei Institute of Geography, 1983) (Fig. 1). Dense reedbeds of Phragmites grow on shallower areas within Lake Baiyangdian, and species of Typha, Myriophyllum, Nelumbo, Nymphoides and Potamogeton all colonise areas of open water (Xu et al., 1988).

Lake Baiyangdian lies in the warm temperate continental monsoon climate zone. The mean annual temperature is $12.1{ }^{\circ} \mathrm{C}$ with January means of $-5.1{ }^{\circ} \mathrm{C}$ and July means of $26.3^{\circ} \mathrm{C}$. Mean annual precipitation is about $464 \mathrm{~mm}$, about 55\% of which falls between July and August. These climate data were calculated on the basis of the daily weather records from the year of 1981 and 2000 of the meteorological station of Gaoyang County, $20 \mathrm{~km}$ away from Lake Baiyangdian. During the sampling year, the total annual precipitation was $430 \mathrm{~mm},>60 \%$ of which fell as rain in August of 2006 and July of 2007, and no recorded flooding occurred (climate data come from Hebei Province Meteorological Bureau), therefore it can be considered a representative year.

The potential vegetation of the area is temperate broad-leaved deciduous forest, but the area is heavily modified by human activity, with only small patches of plantation or secondary forests surviving in the western mountain areas. Most areas of the plain below $100 \mathrm{~m}$ altitude in the catchment of Lake Baiyangdian are cultivated. Planted Populus, Salix, Ulmus, Sophora, Ailanthus and other trees are scattered in the towns, the villages and along the roads (Fig. 2).
In the hilly areas and foothills between 100 and $800 \mathrm{~m}$ a.s.l., the main vegetation type is brushwood and grassland, dominated by Vitex negundo, Ziziphus jujube, Bothriochloa ischaemum, Themeda triandra, Leapedeza bicolor and Spiraea salicifolia. Platycladus orientalis, Pinus tabuliformis, Cotinus coggygria and Robinia pseudoacacia can be dominant in areas with high soil moisture whilst Malus sieversii, Pyrus spp., Zizyphus jujube, Amygdalus persica, Juglans regia and Diospyros kaki are often planted in and around villages. Between 800 and $1500 \mathrm{~m}$ a.s.l., mixed temperate forests still dominate, mainly consisting of Pinus and Quercus, with Betula, Populus davidiana etc., and are replaced between 1500 and $2000 \mathrm{~m}$ a.s.l. by mixed forests of Betula and Picea meyeri. Between 2000 and $2500 \mathrm{~m}$ a.s.l., coniferous forest dominated by Larix principis-rupprechtii forms the upper forested zone and above $2500 \mathrm{~m}$ a.s.l. by subalpine meadow dominated by Kobresia bellardii, Carex tristachya, Ptilagrostis spp., Polygonum viviparum and Saussurea stella (Editing Committee of Hebei Vegetation, 1988).

\section{Methods}

The study was designed on the assumption that pollen entered the lake by two main routes, via aerial and water transport. The pollen grains in the traps above the lake water level are assumed to be transported by wind, pollen grains in the traps below the water surface could have been transported by wind and water, and pollen assemblages in the surface sediment are assumed to be a mixture of pollen grains transported by both wind and water which has

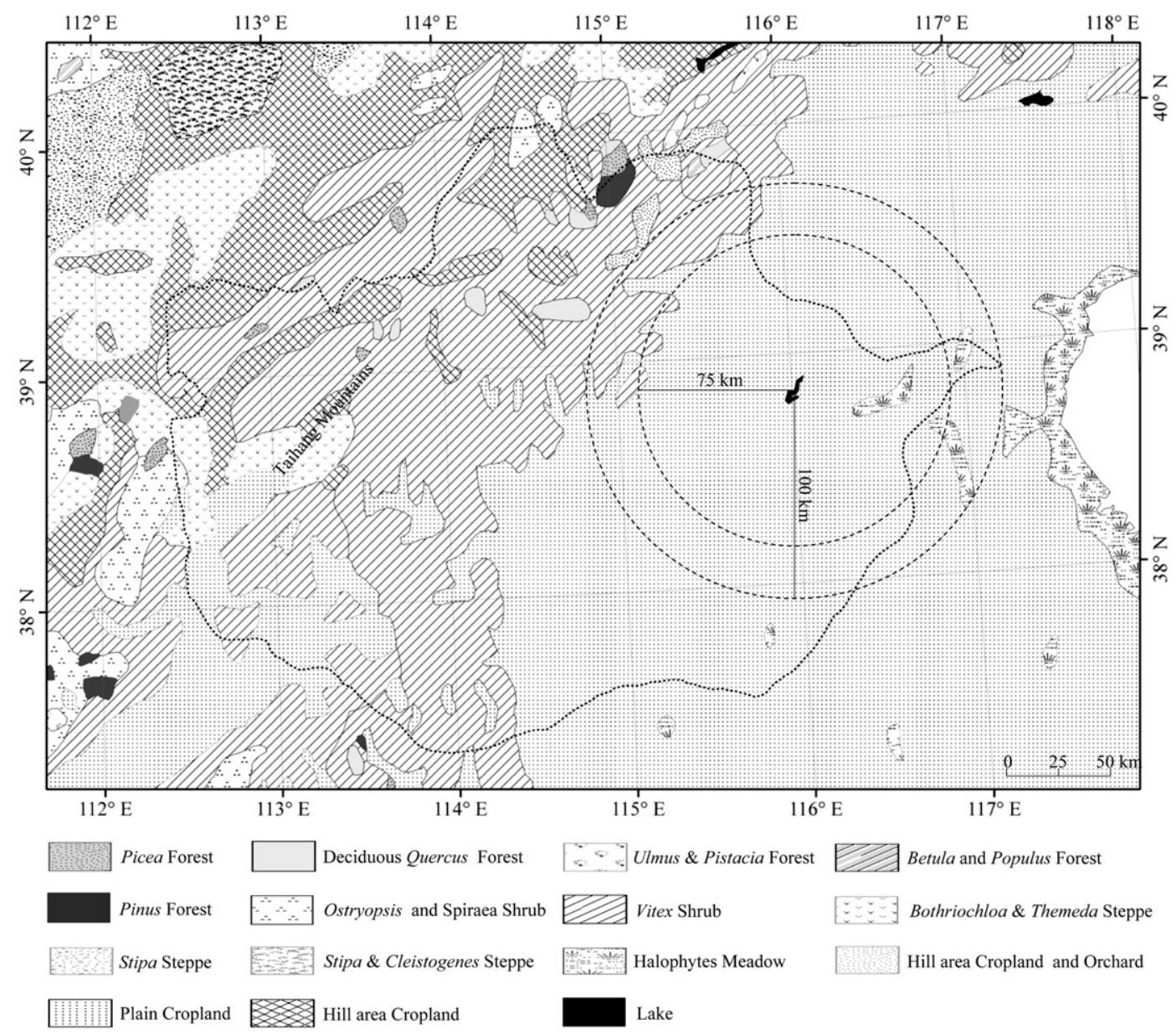

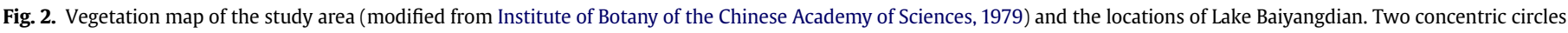
represent potential aerial pollen source radius. 
accumulated over several years. Water transported pollen could either be carried in via the rivers or through overland flow.

\subsection{Field work}

In order to determine the contribution of airborne and waterborne pollen to the pollen assemblages of Lake Baiyangdian, tauber traps (Tauber, 1967) were placed in pairs. One trap was placed $30-40 \mathrm{~cm}$ above the water surface and the second trap was placed below the water surface in areas with water depth $1.5-2 \mathrm{~m}$ with the trap opening $60 \mathrm{~cm}$ above the lakebed to minimise contributions from resuspended lake sediment (Tian et al., 2008). A surface sediment sample (the top 2-3 cm) was collected near each trap pair using a specially-made sampler (with four holes in the top and a moving valve in the bottom). Ten pairs of traps were placed in July, 2006, but only six pairs were retrieved in July, 2007 (locations shown in Fig. 1). Data from these six locations are considered in this paper.

\subsection{Laboratory work}

Ten gram subsamples of lake surface sediment were treated to concentrate pollen as described by Faegri and Iversen (1989). The trap samples were first sieved through $200 \mu \mathrm{m}$ mesh screens to remove insects, small animals (lizards) and coarse plant remains, and then one Lycopodium tablet ( $27637 \pm 563$ grains) was added as tracer to each sample. After that, samples were treated with $10 \%$ $\mathrm{NaOH}$, washed with distilled water and acetolysis carried out using a mixture of acetate anhydride and sulphuric acid in the ratio 9:1. Finally samples were washed with distilled water and centrifuged before being mounted on slides in glycerine for counting. All samples were counted with a BX-51 Olympus light microscope at $400 \times$ magnification and more than 400 pollen grains were counted for each sample.

\subsection{Calculation of pollen influx of trap sample}

Pollen influx was calculated as following:

Pollen influx of type $i\left(\right.$ grains $\left.\mathrm{cm}^{-2} \mathrm{a}^{-1}\right)=\left(P_{i j} \times N\right) /\left(C_{j} \times S\right)$

Where $P_{i j}=$ count of pollen type $i$ in sample $j ; N=$ number of Lycopodium added to the sample; $C_{j}=$ count of Lycopodium tracer in sample; $S=$ opening area $\left(\mathrm{cm}^{2}\right)$ of Tauber trap. In this study, the diameter of the openings in traps above the water level was $5.2 \mathrm{~cm}$, and of traps below the water level was $7.8 \mathrm{~cm}$.

\subsection{Statistical analysis}

Discriminant Analysis and Cluster Analysis are effective methods of measuring the similarities and dissimilarities among pollen assemblages (Liu and Lam, 1985; Lynch, 1996; Reese and Liu, 2005). Here, Discriminant Analysis and Cluster Analysis were carried out on a dataset of pollen percentages of 15 major taxa, including Pinus, Betula, Quercus, Populus, Salix, Ulmus, Elaeagnaceae, Ostryopsis, Artemisia, Poaceae, Chenopodiaceae, Compositae, Humulus, Urtica and Polygonum. Discriminant Analysis was carried out in SPSS and grouping validity was analyzed via a stepwise method. The Bray Curtis coefficient was used to quantify the pollen assemblage dissimilarity between sample pairs (Bray and Curtis, 1957; Legendre and Legendre, 1998) in Cluster Analysis, which was carried out in MVSP 3.1 (Pei, 1990; Xu et al., 2007).

\section{Results}

\subsection{Pollen source areas of Lake Baiyangdian}

\subsubsection{Source areas of airborne pollen}

Pollen fall speeds were calculated according to the methods provided by Duffin and Bunting (2008) (Table 1). Percentage pollen source areas of major taxa were then calculated using the Sutton distance weighting model (Prentice et al., 1987) (Fig. 3). As the outline of Lake Baiyangdian is crescentic, we estimated the lake radius as half of the maximum lake width in the sampling area (4125 m). Wind speed is usually assumed to be constant in many studies (Sugita, 1994; Sugita et al., 1999; Broström et al., 2004; Bunting et al., 2004), but changes in modeled wind speed have obvious influence on model outputs (e.g. Mazier et al., 2008). Therefore, in this paper, percentage pollen source areas of 13 major pollen types (Artemisia, Chenopodiaceae, Poaceae, Urtica, Pinus, Quercus, Salix, Betula, Ulmus, Populus, Elaeagnus, Ostryopsis and Compositae) were calculated based on wind speed of $2.1 \mathrm{~m} \mathrm{~s}^{-1}$ (annual mean wind speed) and $3.2 \mathrm{~m} \mathrm{~s}^{-1}$ (mean wind speed in April, annual maximum) respectively and compared.

Percentage pollen source area decreases with increasing fall speed. If the pollen source area for the whole assemblage is defined as the distance where the rate of increase of pollen contribution of almost all pollen types no longer increases substantially with increasing distance, then these results imply that this distance is about $75 \mathrm{~km}$ when the annual mean wind speed $2.1 \mathrm{~m} \mathrm{~s}^{-1}$ is used, and $100 \mathrm{~km}$ with a wind speed of $3.2 \mathrm{~m} \mathrm{~s}^{-1}$. Since 9 of the 13 pollen taxa originate from trees or shrubs, the corresponding plants usually flower in spring when the wind is stronger in the Baiyangdian area, and we suggest that $100 \mathrm{~km}$ radius is the better estimate of the airborne pollen source area for Lake Baiyangdian using this definition. 'Local' vegetation is therefore that found within $100 \mathrm{~km}$, whilst vegetation beyond $100 \mathrm{~km}$ is considered regional. Most of the local area is the North China Plain. The border with the mountain area to the west occurs about $100 \mathrm{~km}$ from the lake (see Fig. 1). Pollen of Populus, Salix, Ulmus and Ailanthus, which are planted in towns, village and roads in the plains area, will mainly originate within the local pollen catchment, whilst Pinus, Betula, Quercus, Elaeagnus and Ostryopsis which grow in the mountain area are considered regional pollen taxa.

\subsection{Pollen assemblages and pollen influx}

69 pollen types were identified from the 18 samples (Figs. 4-6 show the main pollen types). Some entomophilous pollen types such as Caryophyllaceae, Leguminosae, Liliaceae, Iridaceae,

Table 1

Fall speed $\left(\mathrm{m} \mathrm{s}^{-1}\right)$ of major pollen types.

\begin{tabular}{lll}
\hline Pollen types & Fall speed $\left(\mathrm{m} \mathrm{s}^{-1}\right)$ & Reference \\
\hline Artemisia & 0.015 & This paper $^{\mathrm{a}}$ \\
Chenopodiaceae & 0.029 & This paper \\
Poaceae & 0.035 & $\mathrm{a}$ \\
Urtica & 0.008 & This paper $^{\mathrm{a}}$ \\
Pinus & 0.031 & $\mathrm{~b}$ \\
Quercus & 0.042 & This paper $^{\mathrm{a}}$ \\
Salix & 0.022 & $\mathrm{c}$ \\
Betula & 0.031 & This paper $^{\mathrm{a}}$ \\
Ulmus & 0.032 & $\mathrm{c}$ \\
Populus & 0.020 & This paper $^{\mathrm{a}}$ \\
Elaeagnus & 0.048 & This paper $^{\mathrm{a}}$ \\
Ostryopsis & 0.025 & This paper $^{\mathrm{a}}$ \\
Compositae & 0.051 & $\mathrm{~d}$ \\
\hline
\end{tabular}

a, Sugita et al., 1999; b, Eisenhut (1961); c, Gregory (1973); d, Broström et al. (2004).

a The pollen fall speed of each pollen type is calculated using the geometric method outlined in Gregory (1973) based on measurements of axis length for 100 pollen grains from samples collected in Lake Baiyangdian. 

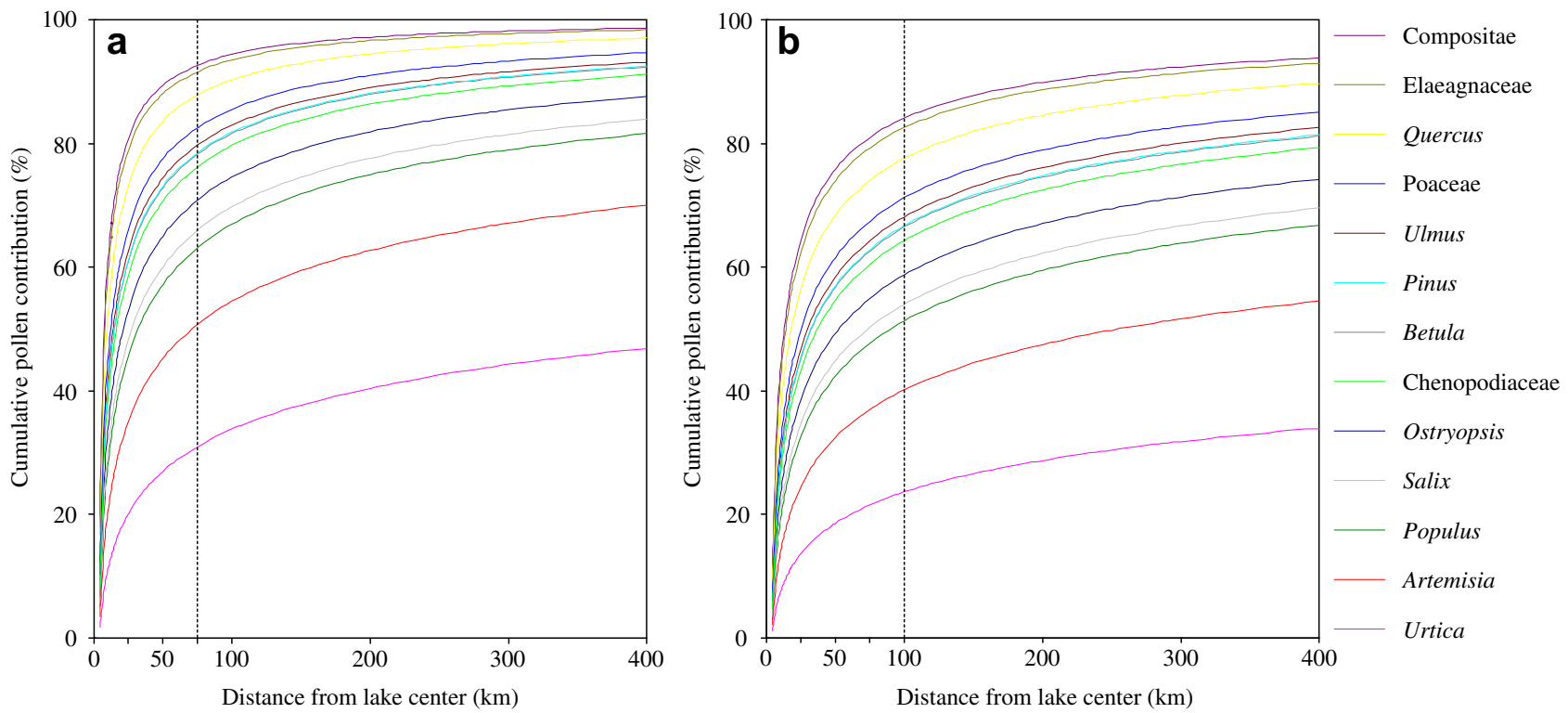

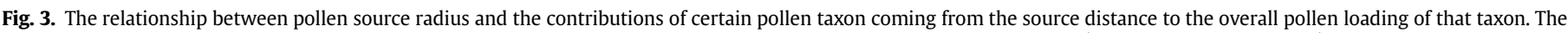
dashed line indicates a potential pollen source radius for major pollen types of Lake Baiyangdian. a: wind speed, $2.1 \mathrm{~m} \mathrm{~s} \mathrm{~s}^{-1}$, b: wind speed, $3.2 \mathrm{~m} \mathrm{~s}^{-1}$.

Malvaceae and Spiraea were not recorded in the traps below the water surface, whilst some large-grained taxa such as Picea and Abies only appeared in the traps below the water surface (Table 2). Proportions of mountain arboreal and shrubby pollen types are higher in traps above the water surface than the traps below the water surface (Table 2).

Traps positioned above the water surface record 56 taxa (Table 2), of which $36 \%$ are mountain types. The mean nonhygrophyte pollen influx is 470 grains $\mathrm{cm}^{-2} \mathrm{a}^{-1}$ (range $170-910$ grains $\mathrm{cm}^{-2} \mathrm{a}^{-1}$ ) and the mean hygrophyte pollen influx is 740 grains $\mathrm{cm}^{-2} \mathrm{a}^{-1}$, range $380-1860$ grains $\mathrm{cm}^{-2} \mathrm{a}^{-1}$.

Traps positioned below the water surface record 52 types (Table 2), $24 \%$ of which are mountain types. The mean nonhygrophyte pollen influx is 5470 grains $\mathrm{cm}^{-2} \mathrm{a}^{-1}$ (range
270-12820 grains $\mathrm{cm}^{-2} \mathrm{a}^{-1}$ ) and the mean hygrophyte pollen influx is 3520 grains $\mathrm{cm}^{-2} \mathrm{a}^{-1}$ (range $160-9490$ grains $\mathrm{cm}^{-2} \mathrm{a}^{-1}$ ).

Sediment-water interface samples contained 55 pollen types (Table 2 ), of which $13 \%$ are mountain types.

\subsection{Comparison of pollen assemblages}

The cross-validation process within the Discriminant Analysis shows that the accuracy rates are all higher than $80 \%$, indicating credible results (Table 3, Fig. 7). The results show that the three types of samples were clearly distinguished, and suggest that location within the site is a less important control on pollen assemblage composition than sampling method. Results of Cluster Analysis are presented in Fig. 8, and Bray-Curtis dissimilarity

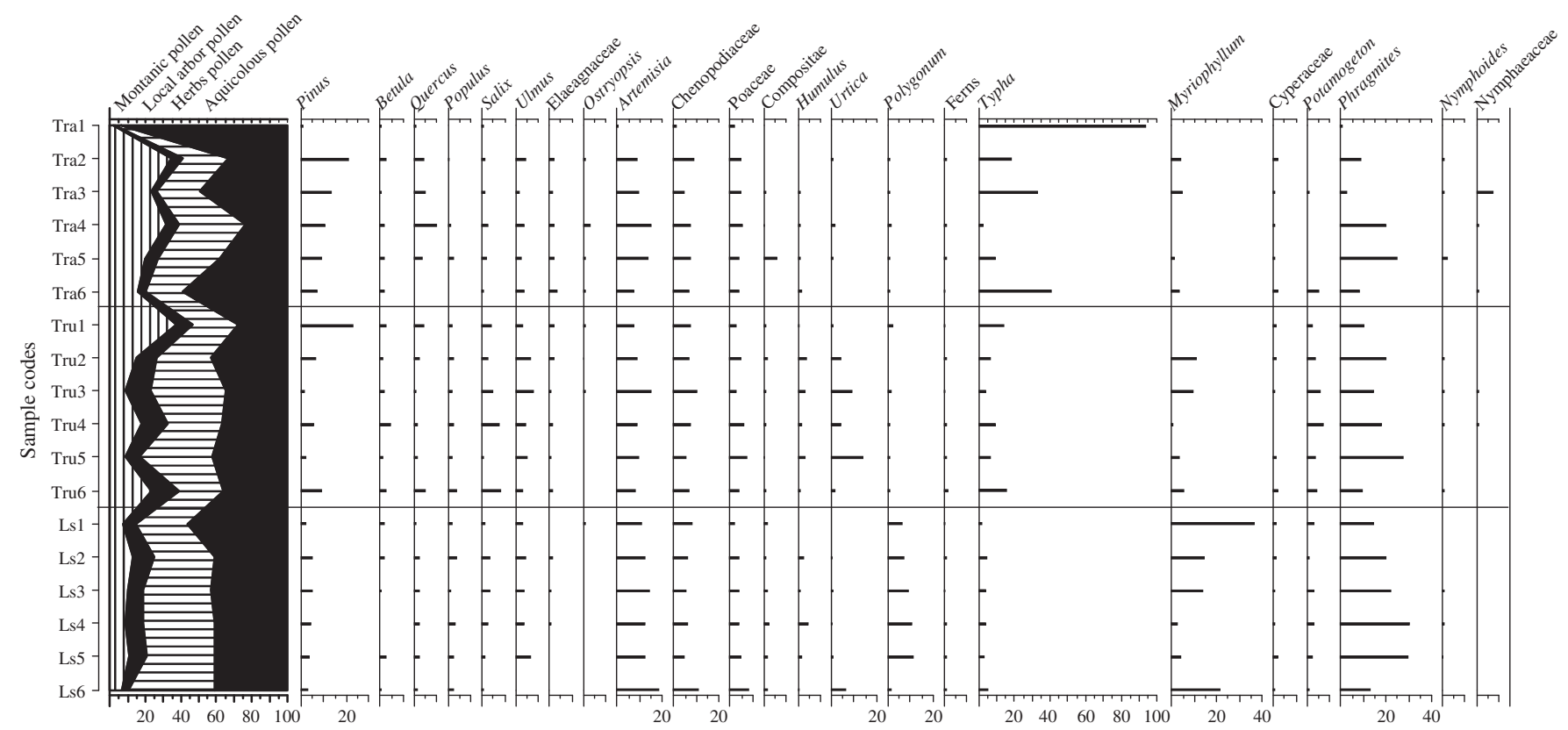

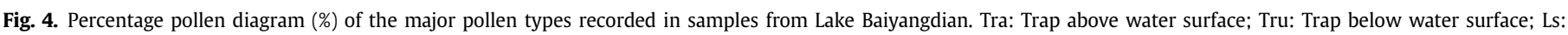
Surface sediment 


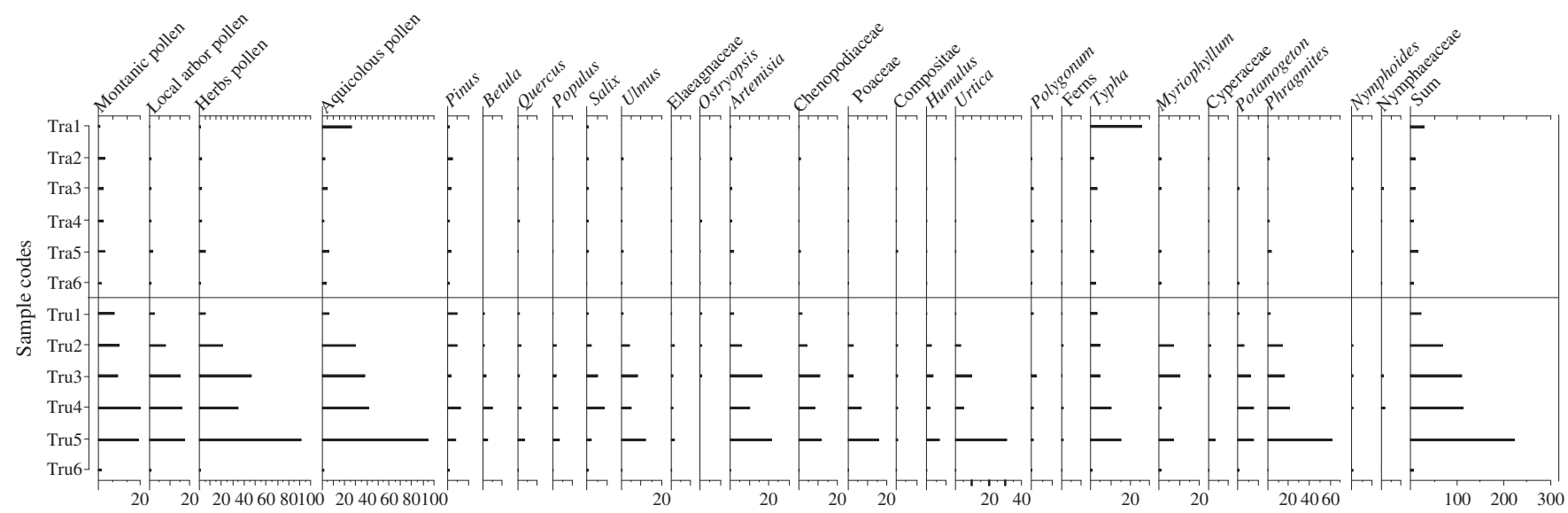

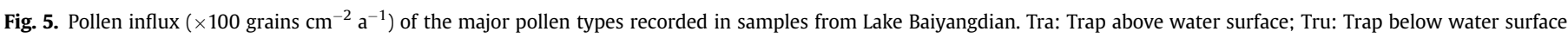

coefficients for all samples are shown in Table 4. The results of Cluster Analysis (Fig. 8) show that pollen assemblages from traps below the water surface are more similar to those from lake surface sediment than those from aerial traps.

\section{Discussion}

One striking characteristic of the pollen assemblages presented here is that some large-grained taxa such as Picea and Abies are only recorded in the traps below the water surface, whilst some entomophilous pollen types such as Caryophyllaceae, Leguminosae, Liliaceae, Iridaceae, Malvaceae and Spiraea were only recorded in traps above the water surface (Table 2). Picea and Abies plants are not found in the North China plain but do grow in the Taihang Mountains (Fig. 2). Both types are large grains, with fall speeds in excess of all the taxa modeled in Fig. 2 (see also Table 1) - Jackson and Lyford (1999) review the available literature and give median fall speeds of $0.100 \mathrm{~m} \mathrm{~s}^{-1}$ for Abies and $0.052 \mathrm{~m} \mathrm{~s}^{-1}$ for Picea - so the estimated aerial percentage pollen source area of these taxa is less than $100 \mathrm{~km}$. Picea pollen is usually interpreted as a watertransported pollen type in the sedimentary record ( $\mathrm{Li}, 1991$; Huang et al., 2004). The absence of Picea and Abies from the aerial trap pollen assemblages is in accordance with these data, since the large distance from the source in the Taihang Mountains means that their contribution to the aerial pollen signal will be very small and unlikely to be detected in a count of a few hundred grains. Their presence in the underwater traps and surface sediment samples supports our argument that these traps contain a substantial element transported by river from Taihang Mountains.

The presence of entomophilous taxa in only the aerial traps illustrates one of the disadvantages of using Tauber traps as a proxy for lake sediment records. Insects enter the traps in pursuit of food, shelter or to drink the water that accumulates, and either shed some of their pollen load or become trapped and die within the trap, leading to enhanced representation of both obligate and facultative entomophilous pollen taxa. The overall proportion of these types is not large, suggesting that in this case insect-borne pollen is only a minor component of the aerial trap assemblage.

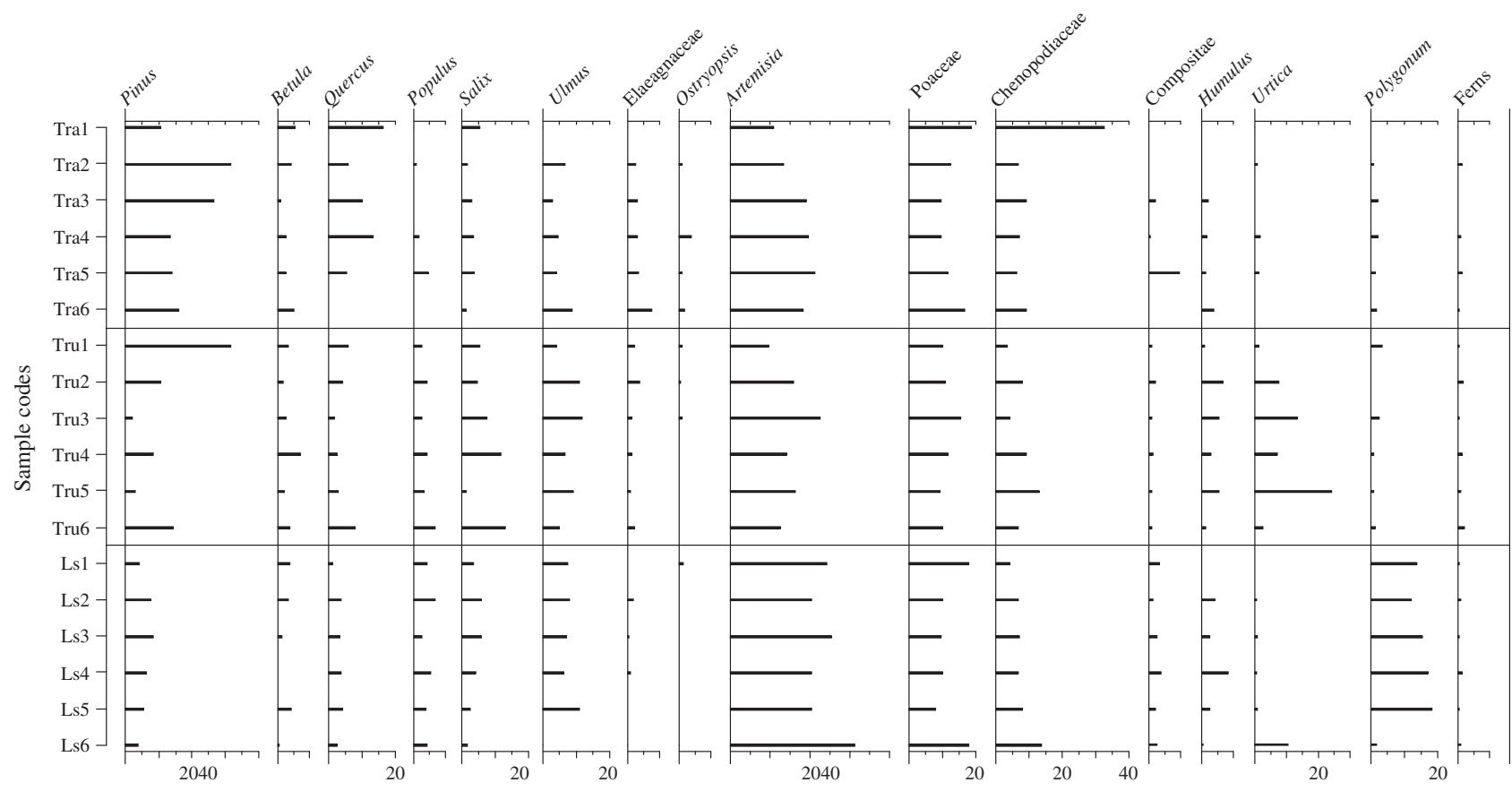

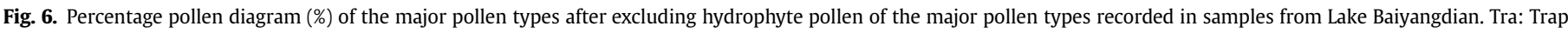
above water surface; Tru: Trap below water surface; Ls: Surface sediment. 
Table 2

Summary of pollen assemblages of three kinds of samples.

\begin{tabular}{|c|c|c|c|c|}
\hline & Common taxa & Aerial trap & Trap below water & Surface sediment \\
\hline $\begin{array}{l}\text { Mountains trees } \\
\text { and shrubs }\end{array}$ & $\begin{array}{l}\text { Pinus, Betula, Juglans, Quercus, Cotinus, } \\
\text { Rhamnaceae, Oleaceae, } \\
\text { Nitraria, Ostryopsis, Elaeagnaceae }\end{array}$ & $\begin{array}{l}\text { Moraceae, Pteroceltis, } \\
\text { Spiraea, Vitex }\end{array}$ & $\begin{array}{l}\text { Picea, Abies, Acer, } \\
\text { Alnus, Carpinus, } \\
\text { Celtis, Pteroceltis, } \\
\text { Tilia, Corylus }\end{array}$ & $\begin{array}{l}\text { Alnus, Celtis, Picea, Carpinus, } \\
\text { Moraceae, Corylus, Cornaceae }\end{array}$ \\
\hline $\begin{array}{l}\text { Woods both in plains } \\
\text { and mountain }\end{array}$ & Populus, Salix, Ulmus, Ailanthus, Tamarix & & & \\
\hline Mountain herbs & Thalictrum, Ranunculaceae & $\begin{array}{l}\text { Campanulaceae, } \\
\text { Caryophyllaceae, } \\
\text { Iridaceae, Pedicularis }\end{array}$ & $\begin{array}{l}\text { Campanulaceae, } \\
\text { Sanguisorba }\end{array}$ & $\begin{array}{l}\text { Geraniaceae, Iridaceae, } \\
\text { Scrophulariaceae }\end{array}$ \\
\hline $\begin{array}{l}\text { Herbs both in plains } \\
\text { and mountain }\end{array}$ & $\begin{array}{l}\text { Artemisia, Chenopodiaceae, Compositae, } \\
\text { Convolvulaceae, Humulus, Labiatae, Poaceae, } \\
\text { Rosaceae, Cucurbitaceae, Urtica, } \\
\text { Solanaceae, Polygonum }\end{array}$ & $\begin{array}{l}\text { Leguminosae, Liliaceae, } \\
\text { Malvaceae }\end{array}$ & Cruciferae & $\begin{array}{l}\text { Cruciferae, Leguminosae, } \\
\text { Plantaginaceae, Umbelliferae }\end{array}$ \\
\hline Plains Aquatic plants & $\begin{array}{l}\text { Cyperaceae, Myriophyllum, Phragmites, } \\
\text { Potamogeton, Nymphoides peltatum, Typha }\end{array}$ & Nymphaeaceae & Nymphaeaceae & \\
\hline
\end{tabular}

Discriminant Analysis reveals that the differences between pollen assemblages collected using different methods are more significant than differences between assemblages collected at different points in the lake (Fig. 7), and Cluster Analysis (Fig. 8) shows that the pollen assemblages in traps below the surface are relatively similar to those from sediment samples, but differ from the pollen assemblages trapped above the surface. The results of both analyses suggest that transport agents have significant effect on the lacustrine pollen assemblage.

\subsection{Pollen transport mechanisms in Lake Baiyangdian}

A simple model of the pollen sources for a lake with inflowing streams is given by:

$L=A+W$

Where $L$ : lacustrine pollen; $A$ : airborne pollen; $W$ : waterborne pollen

In this study, aerial traps record the aerial component for the year July 2006 to July 2007, the $A_{2006-7}$ component. Traps in the water column record both $A_{2006-7}$ and $W_{2006-7}$, and sediment samples contain both $A$ and $W$ for an unknown number of years prior to sample collection in 2007.

Comparing aerial traps (mean pollen influx 1210 grains $\mathrm{cm}^{-2} \mathrm{a}^{-1}$ ) and traps in the water column (mean pollen influx 8990 grains $\mathrm{cm}^{-2} \mathrm{a}^{-1}$ ) allows calculation of an estimate of $\mathrm{W}_{2006-7}$ at 7490 grains $\mathrm{cm}^{-2} \mathrm{a}^{-1}$, suggesting that airborne pollen accounts for around $12 \%$ of the total pollen influx to Lake Baiyangdian in 2006-7. When hygrophyte pollen types are removed from the influx data, $W_{2006-7}$ is estimated as 5470 grains $\mathrm{cm}^{-2} \mathrm{a}^{-1}$ and airborne pollen makes up only about $8 \%$ of the total influx into Lake

Table 3

Classification results of discriminant analysis of all samples.

\begin{tabular}{|c|c|c|c|c|c|c|}
\hline & & \multirow[t]{2}{*}{ Sample codes } & \multicolumn{3}{|c|}{ Predicted group membership } & \multirow[t]{2}{*}{ Total } \\
\hline & & & 1 & 2 & 3 & \\
\hline \multirow[t]{6}{*}{ Original } & Count & 1 & 6 & 0 & 0 & 6 \\
\hline & & 2 & 0 & 6 & 0 & 6 \\
\hline & & 3 & 0 & 0 & 6 & 6 \\
\hline & $\%$ & 1 & 100 & 0 & 0 & 100 \\
\hline & & 2 & 0 & 100 & 0 & 100 \\
\hline & & 3 & 0 & 0 & 100 & 100 \\
\hline \multirow[t]{6}{*}{ Cross-validated } & Count & 1 & 5 & 0 & 1 & 6 \\
\hline & & 2 & 0 & 6 & 0 & 6 \\
\hline & & 3 & 1 & 0 & 5 & 6 \\
\hline & $\%$ & 1 & 83.3 & 0 & 16.7 & 100 \\
\hline & & 2 & 0 & 100 & 0 & 100 \\
\hline & & 3 & 16.7 & 0 & 83.3 & 100 \\
\hline
\end{tabular}

Baiyangdian in 2006-7. Peck (1973) reports that the waterborne component in Lake Oakdale is up to $97 \%$ of the total pollen count, and Bonny (1978) finds that $87 \%$ of the pollen assemblage in Blelham Tarn is probably transported by rivers; despite the size difference between the lakes studied, the findings are similar to those from Lake Baiyangdian. The primary control on the proportion of aerial to waterborne pollen is likely to be the ratio between river length/input and lake surface area (the aerial pollen 'trap'), rather than lake size directly.

Hydrophyte plants such as Cyperaceae, Phragmites, Typha and Nymphaeaceae grow in shallower parts of the lake basin (Fig. 1c) and in the lake margins, and can also be found in suitable habitats in the wider landscape and in ditches, albeit in much smaller numbers, and they produce pollen above the water allowing for aerial dispersal mechanisms. In the aerial traps, the ratio of pollen types from obligate dry-land plants to hydrophytic plants $(\mathrm{T} / \mathrm{H})$ will broadly reflect the vegetation in the local area since the hydrophytes mainly originate within and adjacent to the lake and the aerial pollen source area is estimated as confined to the North China Plain. This can be contrasted with the pollen assemblages from the underwater traps or the sediment, where the hydrophyte pollen could have originated from the same aerial sources, from overland flow (which will bring in both hydrophyte pollen and aerially transported pollen which has landed on the ground surface from the local area around the lake) or from river flow in the aerial pollen source radius (which will include some hydrophyte pollen from the river margins). If overland flow dominates the waterborne pollen signal, the $\mathrm{T}: \mathrm{H}$ ratio is expected to be similar for aerial traps and underwater traps. If river-borne pollen is significant in the waterborne component we would expect the $\mathrm{T}: \mathrm{H}$ ratio to be higher than in the aerial traps. For aerial traps, the mean $\mathrm{T}: \mathrm{H}$ is 0.64 , whilst for underwater traps it is 1.55 , supporting the argument that riverborne pollen makes a significant contribution to the assemblages in the water column. However, the proportionate increase in terrestrial types is not as large as would be expected if no overland flow contributed to the pollen assemblages suggesting that overland flow from the local area might be an important fraction of the waterborne pollen assemblage and Eq. (1) should be written as:

$L=A+W_{o}+W_{r}$

Where $L=$ Lacustrine pollen; $A=$ airborne pollen; $W_{o}=$ waterborne pollen from overland flow and $W_{r}=$ fluvial waterborne pollen

Assuming that the $\mathrm{T}: \mathrm{H}$ ratio from the aerial traps is also a good estimate for the overland flow component, it is possible to estimate constants for Eq. (3) for Lake Baiyangdian as:

$L=0.09 A+0.33 W_{o}+0.58 W_{r}$ (see appendix for calculations) 


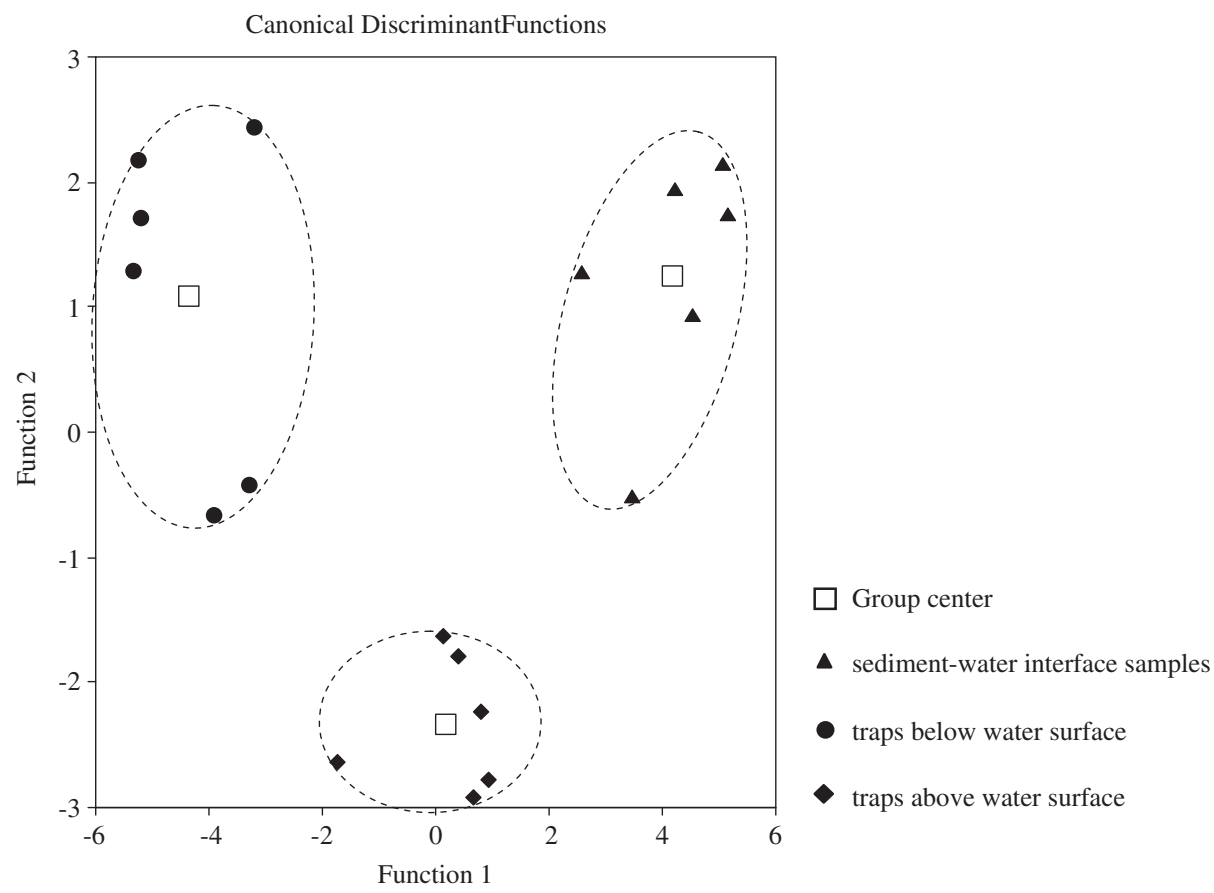

Fig. 7. Results of Discriminant Analysis of the three types of pollen sample.

These are crude initial estimates only. Overland flow is particularly tricky to investigate, and pollen transported by overland flow may have been exposed to oxidative degradation whilst lying on the ground surface for some months, leading to a reduction in proportions of less robust pollen types such as Cyperaceae. However, this equation sets up a useful hypothesis for testing in future research.

\subsection{The source area of major pollen taxa in Lake Baiyangdian}

Assumptions about pollen transporting agencies and pollen source areas are key components when reconstructing palaeovegetation and palaeoclimate from lake sediment pollen records. Current pollen dispersal and deposition models seem to be able to estimate pollen source area quite effectively for lakes without inflowing rivers, but such sites are rare in nature. In this study, we estimate the percentage aerial pollen source area of common pollen taxa in Lake Baiyangdian to be about $100 \mathrm{~km}$ radius. The Taihang Mountains lie beyond this distance, but inflowing rivers carry mountain pollen taxa which are incorporated into pollen traps placed below the water surface and into surface sediment pollen assemblages, but are absent from aerial pollen traps. In reconstructing palaeovegetation and palaeoclimate from lacustrine pollen records from sites with inflowing rivers, it is important to consider that the fossil pollen assemblages could contain a large portion of waterborne pollen, which has a source area of the entire drainage area, rather than aerially transported pollen, which is assumed to have a roughly circular source area.

The potential aerial pollen area of Lake Baiyangdian is occupied by the North China Plain which is vegetated with cultivated plants (mainly wheat and maize) (Fig. 2). These taxa typically have low pollen productivities compared to trees, the grains are

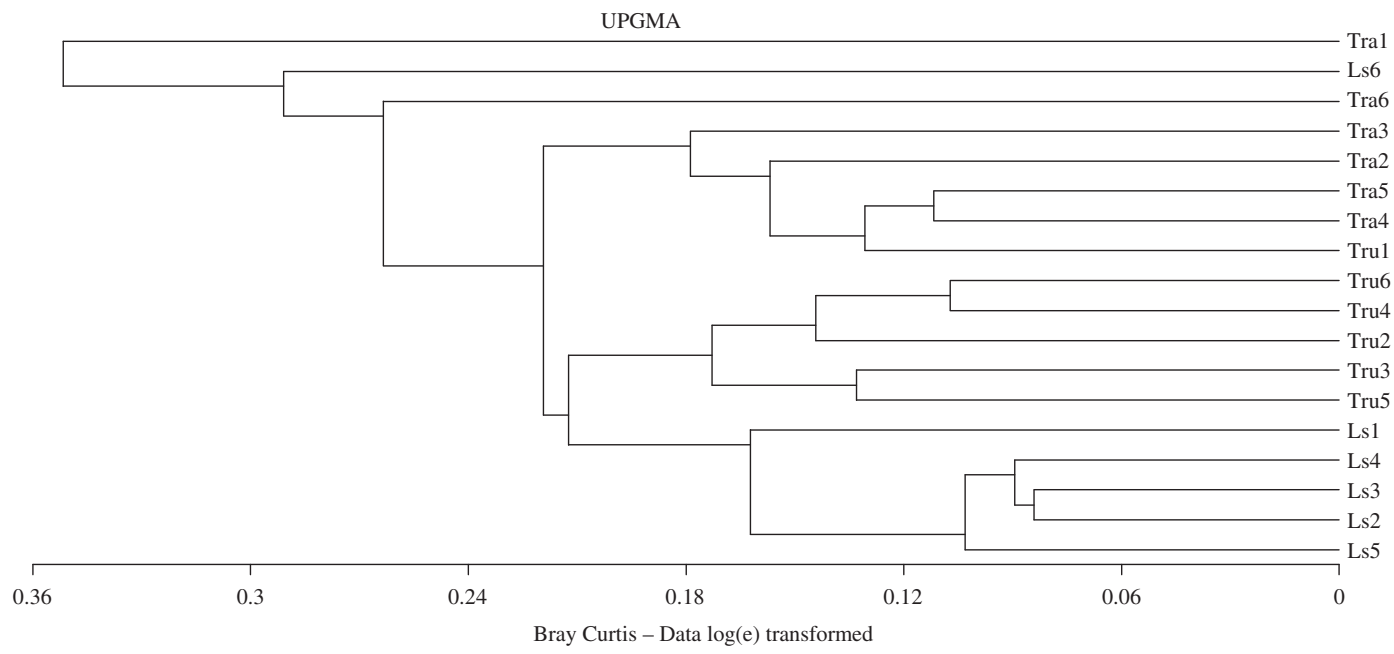

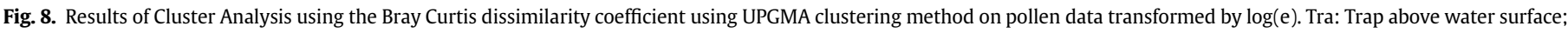
Tru: Trap below water surface; Ls: Surface sediment. 
Table 4

Bray-Curtis dissimilarity of pollen assemblages between samples.

\begin{tabular}{|c|c|c|c|c|c|c|c|c|c|c|c|c|c|c|c|c|c|c|}
\hline & Tra1 & Tru1 & Ls1 & Tra2 & Tru2 & Ls2 & Tra3 & Tru3 & Ls3 & Tra4 & Tru4 & Ls4 & Tra5 & Tru5 & Ls5 & Tra6 & Tru6 & Ls6 \\
\hline Tra1 & 0 & & & & & & & & & & & & & & & & & \\
\hline Tru1 & 0.320 & 0 & & & & & & & & & & & & & & & & \\
\hline Ls1 & 0.375 & 0.231 & 0 & & & & & & & & & & & & & & & \\
\hline Tra2 & 0.270 & 0.133 & 0.274 & 0 & & & & & & & & & & & & & & \\
\hline Tru2 & 0.365 & 0.205 & 0.280 & 0.224 & 0 & & & & & & & & & & & & & \\
\hline Ls2 & 0.356 & 0.171 & 0.164 & 0.232 & 0.172 & 0 & & & & & & & & & & & & \\
\hline Tra3 & 0.295 & 0.190 & 0.316 & 0.197 & 0.226 & 0.215 & 0 & & & & & & & & & & & \\
\hline Tru3 & 0.432 & 0.211 & 0.226 & 0.285 & 0.158 & 0.186 & 0.316 & 0 & & & & & & & & & & \\
\hline Ls3 & 0.359 & 0.197 & 0.155 & 0.258 & 0.190 & 0.084 & 0.203 & 0.212 & 0 & & & & & & & & & \\
\hline Tra4 & 0.306 & 0.127 & 0.264 & 0.162 & 0.181 & 0.185 & 0.150 & 0.211 & 0.197 & 0 & & & & & & & & \\
\hline Tru4 & 0.322 & 0.199 & 0.264 & 0.217 & 0.121 & 0.145 & 0.250 & 0.156 & 0.180 & 0.200 & 0 & & & & & & & \\
\hline Ls4 & 0.428 & 0.245 & 0.182 & 0.304 & 0.191 & 0.086 & 0.225 & 0.236 & 0.093 & 0.240 & 0.214 & 0 & & & & & & \\
\hline Tra5 & 0.349 & 0.134 & 0.209 & 0.175 & 0.143 & 0.171 & 0.178 & 0.222 & 0.186 & 0.112 & 0.178 & 0.196 & 0 & & & & & \\
\hline Tru5 & 0.410 & 0.273 & 0.311 & 0.267 & 0.148 & 0.205 & 0.291 & 0.133 & 0.230 & 0.237 & 0.142 & 0.235 & 0.241 & 0 & & & & \\
\hline Ls5 & 0.371 & 0.218 & 0.148 & 0.253 & 0.199 & 0.101 & 0.240 & 0.221 & 0.085 & 0.211 & 0.186 & 0.123 & 0.197 & 0.203 & 0 & & & \\
\hline Tra6 & 0.361 & 0.264 & 0.294 & 0.201 & 0.258 & 0.248 & 0.228 & 0.268 & 0.296 & 0.209 & 0.261 & 0.325 & 0.246 & 0.291 & 0.283 & 0 & & \\
\hline Tru6 & 0.297 & 0.121 & 0.273 & 0.173 & 0.167 & 0.139 & 0.196 & 0.216 & 0.194 & 0.132 & 0.107 & 0.218 & 0.125 & 0.217 & 0.203 & 0.280 & 0 & \\
\hline Ls6 & 0.357 & 0.336 & 0.268 & 0.363 & 0.263 & 0.305 & 0.307 & 0.258 & 0.259 & 0.314 & 0.244 & 0.287 & 0.272 & 0.218 & 0.259 & 0.409 & 0.293 & 0 \\
\hline
\end{tabular}

comparatively large and therefore have a short aerial transport distance (Cerealia fall speeds are estimated at $0.060 \mathrm{~m} \mathrm{~s}^{-1}$ and Zea mays fall speeds around $0.100 \mathrm{~m} \mathrm{~s}^{-1}$, Sugita et al., 1999), and Poaceae grains also have relatively poor pollen preservation (Ma et al., 2008; Zheng et al., 2008). These facts mean that these communities would be expected to be under-represented in a pollen record relative to the scrub and woodland vegetation of the Taihang Mountains which will probably have the effect of reducing the aerial contribution to the lake pollen record relative to the fluvial component. Whilst the numerical values for proportions of different components in the record are specific to the present-day landscape, climate and taphonomy of Lake Baiyangdian, the complexity of the pollen signal forming process illustrated by these data is widely applicable to lake records past and present.

\subsection{Comparison with previous studies}

The pollen influx of lakes with no inflow channel is lower than that of sites with an inflow (e.g. Pennington, 1979), which indicates that the pollen brought by river and stream contributes to lake pollen assemblages. Tauber traps are designed as empirical models of pollen assemblage formation in a lake, and this study's findings from aerial and submerged traps show, as expected, higher influx in traps affected by the inflow. Various studies find that inflowing rivers can be the main source of pollen in a lake system (Cross et al., 1966; Peck, 1973; Bonny, 1976, 1978; Vincens and Bonnefille, 1988; DeBusk, 1997). For example, surface sediment pollen studies of three large lakes (Lake Dianchi, Lake Daihai and Lake Bosten) and two relatively small lakes (Lake Duikounao and Lake Hulunnao) in China (see Fig. 1) show that pollen carried by the rivers has a clear effect on the lacustrine pollen assemblages (Sun and Wu, 1987; Huang et al., 2004; Xu et al., 2005; Tian et al., 2008). Pollen influx data from pollen traps allows better quantification of the relative contributions of waterborne and airborne pollen.

\section{Conclusions}

This paper presents results of a modern pollen taphonomic study at Lake Baiyangdian, a large fresh water lake with several inflowing rivers. Comparison of pollen traps above the water with those below implies that the pollen influx to the sediment is dominated by waterborne pollen; around $92 \%$ of the total terrestrial plant pollen influx is waterborne. When interpreting pollen records from lakes with inflowing streams, therefore, the pollen source area of the aerial component is a poor starting point, and a more complex understanding of source area which takes into account the hydrological catchment as well as the aerial pollen source area needs to be developed and applied. Developing methods for estimating pollen source areas for such sites, then considering how (and indeed whether) they can be used to interpret past changes of vegetation and climate, will be a challenging work, but it is clearly necessary if Quaternary scientists are to extract meaningful reconstructions from the problematic but relatively abundant sediments of lakes with inflowing streams.

\section{Acknowledgements}

We thank the two anonymous reviewers for their constructive comments and suggestions which greatly improved the manuscript. This work was supported by the Key National Natural Science Foundation of China (40730103), the National Science Foundation of China (41071132 and 40672107) and Hebei Natural Science Foundation (D2008000186 and D2009000300).

\section{Appendix. Estimating the parameters for the pollen assemblage formation equation pollen influx data}

\begin{tabular}{|c|c|c|}
\hline & $\begin{array}{l}\text { Aerial trap mean } \\
\text { pollen influx } \\
\text { (grains } \mathrm{cm}^{-2} \mathrm{a}^{-1} \text { ) }\end{array}$ & $\begin{array}{l}\text { Underwater trap } \\
\text { mean pollen influx } \\
\text { (grains } \mathrm{cm}^{-2} \mathrm{a}^{-1} \text { ) }\end{array}$ \\
\hline Terrestrial types (T) & 470 & 5470 \\
\hline Hydrophyte types (H) & 740 & 3520 \\
\hline $\mathrm{T}: \mathrm{H}$ ratio & 0.64 & 1.55 \\
\hline
\end{tabular}

If hydrophytic pollen was purely transported via the aerial route, then the amount would be the same in aerial and underwater traps, and the underwater trap T:H ratio would be predicted to be $5470 /$ $740=7.4$

If the underwater traps received pollen from the aerial route and from overland flow, hydrophytic pollen would enter the system via two routes. Assuming that the overland flow picked up pollen deposited onto bare land surfaces through the aerial route, then we would predict that the ratio of terrestrial to hydrophyte pollen types should be the same in both types of traps, i.e. $\mathrm{T}: \mathrm{H}=0.64$. If $\mathrm{T}: \mathrm{H}=0.64$ in the underwater traps then, since an influx of 3520 hydrophyte grains is recorded, we would expect to see about $0.64 \times 3520$ aerial grains $=2250$ aerial grains. Since a substantially larger number of terrestrial grains are recorded, this suggests that 
another source of terrestrial pollen types is present; we infer that this represents the river-borne component of the assemblage.

Assuming that the hydrophyte component is sourced from aerial and overland flow only, the increase in hydrophytes in the underwater trap over the aerial trap reflects influx from overland flow, and the runoff component can be estimated as contributing about 2780 grains $\mathrm{cm}^{-2} \mathrm{a}^{-1}$ to the hydrophyte part of the forming assemblage (influx estimated as $3520-740 \approx 2780$ grains $\mathrm{cm}^{-2} \mathrm{a}^{-1}$ ). Both of these components are assumed to have the same T:H ratio, estimated as 0.64 for the aerial component, which implies that the terrestrial pollen component entering the lake as part of the overland flow would be $0.64 \times 2780$ or about 1780 grains $\mathrm{cm}^{-2} \mathrm{a}^{-1}$.

The measured terrestrial pollen component in the waterborne traps is 5470 grains $\mathrm{cm}^{-2} \mathrm{a}^{-1}$, which we can now break down into three parts; roughly 470 grains from the aerial route, 1780 grains from the overland flow route and 3220 grains from the fluvial transport route.

On this basis, we estimate the sources of pollen entering the submerged trap (and, we infer, the lake sediment) in the study period as follows:

\begin{tabular}{|c|c|c|c|c|}
\hline \multirow{2}{*}{$\begin{array}{l}\text { Taphonomic } \\
\text { route }\end{array}$} & \multicolumn{2}{|l|}{ Hydrophyte pollen } & \multicolumn{2}{|l|}{ Terrestrial pollen } \\
\hline & $\begin{array}{l}\text { Influx } \\
\text { (grains } \mathrm{cm}^{-2} \mathrm{a}^{-1} \text { ) }\end{array}$ & Percentage & $\begin{array}{l}\text { Influx } \\
\text { (grains } \mathrm{cm}^{-2} \mathrm{a}^{-1} \text { ) }\end{array}$ & Percentage \\
\hline Aerial & 740 & $21 \%$ & 470 & $9 \%$ \\
\hline Overland flow & 2780 & $79 \%$ & 1780 & $33 \%$ \\
\hline River transport & 0 & $0 \%$ & 3220 & $58 \%$ \\
\hline
\end{tabular}

The river transport component will include both grains of mountain types carried from the upper parts of the catchment and grains collected during travel through the lowland part of the catchment, therefore the proportion of mountain pollen types in the submerged traps and the sediment-water interface samples should be substantially lower than the total river transport proportion, which is seen in the data ( $24 \%$ and $13 \%$ respectively).

\section{References}

Bonny, A.P., 1976. Recruitment of pollen to the section and sediment of some district lakes. Journal of Ecology 64, 859-887.

Bonny, A.P., 1978. The effect of pollen recruitment processes on pollen distribution over the sediment surface of a small lake in Cumbria. Journal of Ecology 66, $385-416$.

Bray, J.R., Curtis, J.T., 1957. An ordination of upland forest communities of southern Wisconsin. Ecological Monographs 27, 325-349.

Broström, A., Sugita, S., Gaillard, M.J., 2004. Pollen productivity estimates for the reconstruction of past vegetation cover in the cultural landscape of southern Sweden. The Holocene 14, 368-381.

Brown, A.G., Carpenter, R.G., Walling, D.E., 2007. Monitoring fluvial pollen transport, its relationship to catchment vegetation and implications for palaeoenvironmental studies. Review of Palaeobotany and Palynology 147, 60-76.

Brush, G.S., Brush, L.M.J., 1972. Transport of pollen in a sediment laden channel: a laboratory study. American Journal of Science 272, 359-381.

Bunting, M.J., Middleton, R., 2009. Equifinality and uncertainty in the interpretation of pollen data: the Multiple Scenario Approach to reconstruction of past vegetation mosaics. The Holocene 19 (5), 799-803.

Bunting, M.J., Gaillard, M.J., Sugita, S., Middleton, R., Broström, A., 2004. Vegetation structure and pollen source area. The Holocene 14, 651-660.

Chen, F.H., Huang, X.Z., Zhang, J.W., Holmes, J.A., Chen, J.H., 2006. Humid little ice age in arid central Asia documented by Bosten Lake, Xinjiang, China. Science in China Series D: Earth Sciences 49 (12), 1280-1290.

Cross, T.A., Thompson, G.G., Zaitzeff, J.B., 1966. Source and distribution of palynomorphs in bottom sediments, southern part of the Gulf of California. Marine Geology 4 (6), 467-524.

DeBusk, G.H., 1997. The distribution of pollen in the surface sediments of Lake Malawi, Africa, and the transport of pollen in large lakes. Review of Palaeobotany and Palynology 97, 123-153.

Duffin, K.I., Bunting, M.J., 2008. Relative pollen productivity and fall speed estimates for southern African savanna taxa. Vegetation History and Archaeobotany 17 (5), 507-525.
Editing committee of Hebei vegetation, 1988. Vegetation of Hebei Province. Science Press, Beijing, pp. 1-364 (in Chinese).

Eisenhut, G., 1961. Untersuchungen über die Morphologie und Ökologie der Pollenkörner heimischer und fremdländischer Waldbäume. Paul Parley, Hamburg, pp. 68 (in German).

Faegri, K., Iversen, J., 1989. Textbook of Pollen Analysis, third ed. Blackwell, Oxford, pp. 1-295.

Fall, P.L., 1981. Modern pollen spectra and their application to alluvial pollen sedimentology (M.S. thesis). University of Arizona, Tucson pp. 63.

Gasse, F., Arnold, M., Frontes, J.C., Fort, M., Gibert, E., Huc, A., Li, B., Li, Y., Liu, Q. Melieres, F., Van Campo, E., Wang, F., Zhang, Q., 1991. A 13,000-year climate record from western Tibet. Nature 353, 742-745.

Gregory, P.H., 1973. The Microbiology of the Atmosphere, second ed. Leonard Hill Books, London, pp. 377.

Hebei Institute of Geography, 1983. Research Atlas for the Protection of Water Sources in the Baiyang Lake. Science Press, Beijing, pp. 1-37 (in Chinese).

Hellman, S., Gaillard, M.J., Broström, A., Sugita, S., 2008. The REVEALS model, a new tool to estimate past regional plant abundance from pollen data in large lakes: validation in southern Sweden. Journal of Quaternary Science 23 (1), 21-42.

Huang, X.Z., Zhao, Y., Cheng, B., Chen, F.H., Xu, J.R., 2004. Modern pollen analysis of the surface sediments from the Bosten Lake, Xinjiang, China. Journal of Glaciology and Geocryology 26 (5), 602-609 (in Chinese with English abstract).

Institute of Botany of the Chinese Academy of Sciences, 1979. China Vegetation Map. Sinomaps Press, Beijing (in Chinese).

Jackson, S.T., Lyford, M.E., 1999. Pollen dispersal models in Quaternary plant ecology: assumptions, parameters, and prescriptions. Botanical Review 65 (1), 39-75.

Jacobson, G.L., Bradshaw, R.H.W., 1981. The selection of sites for paleovegetational studies. Quaternary Research 16 (1), 80-96.

Legendre, P., Legendre, L., 1998. Numerical Ecology, second english ed. Elsevier Science BV, Amsterdam.

Li, W.Y., 1991. Studies on dispersal efficiency of Picea pollen. Acta Botanica Sinica 33 (10), 792-800 (in Chinese).

Liu, K.B., Lam, N.N., 1985. Paleovegetational reconstruction based on modern and fossil pollen data: an application of discriminant analysis. Annals of the Association of American Geographers 75, 115-130.

Liu, C.L., Xie, G.D., Xiao, Y., 2007. Impact of climate change on Baiyangdian wetland. Resources and Environment in the Yangtze Basin 16 (2), 245-250 (in Chinese with English abstract).

Lynch, E.A., 1996. The ability of pollen from small lakes and ponds to sense fine-scale vegetation patterns in the Central Rocky Mountains, USA. Review of Palaeobotany and Palynology 94, 197-210.

Ma, Y.Z., Liu, K.B., Feng, Z.D., Sang, Y.L., Wang, W., Sun, A.Z., 2008. A survey of modern pollen and vegetation along a south-north transect in Mongolia. Journal of Biogeography 35, 1512-1532.

Mazier, F., Broström, A., Gaillard, M.J., Sugita, S., Vittoz, P., Buttler, A., 2008. Pollen productivity estimates and relevant source area of pollen for selected plant taxa in a pasture woodland landscape of the Jura Mountains (Switzerland). Vegetation History Archaeobotany 17, 479-495.

McAndrews, J.H., Power, D.M., 1973. Palynology of the Great Lakes: the surface sediments of Lake Ontario. Canadian Journal of Earth Sciences 10, 777-792.

Parsons, R.W., Prentice, I.C., 1981. Statistical approaches to R-values and the pollen-vegetational relationship. Review of Palaeobotany and Palynology 32 127-152.

Peck, R., 1973. Pollen budget studies in a small Yorkshire catchment. In: Birks, H.J.B. West, R.G. (Eds.), Quaternary Plant Ecology. Blackwell Scientific Publications, Oxford, pp. 43-60.

Peck, R., 1974. Studies of pollen distribution in the Oakdale Catchment (PhD thesis). Cambridge University, Cambridge.

Pei, X.D., 1990. Multi-statistical Analysis and Application. Beijing Agriculture University Press, Beijing, pp. 196-203 (in Chinese).

Pennington, W., 1979. The origin of pollen in lake sediments: an enclosed lake compared with one receiving inflow streams. New Phytologist 83, 189-213.

Prentice, I.C., 1985. Pollen representation, source area, and basin size: toward a unified theory of pollen analysis. Quaternary Research 23, 76-86.

Prentice, I.C., Parsons, R.W., 1983. Maximum Likelihood Linear Calibration of pollen spectra in terms of forest composition. Biometrics 39 (4), 1051-1057.

Prentice, I.C., Berglund, B.E., Olsson, T., 1987. Quantitative forest-composition sensing characteristics of pollen samples from Swedish lakes. Boreas 16 (1), 43-54.

Reese, C.A., Liu, K.B., 2005. A modern pollen rain study from the central Andes region of South America. Journal of Biogeography 32, 709-718.

Solomon, A.M., Blasing, T.J., Solomon, J.A., 1982. Interpretation of floodplain pollen in alluvial sediments from an arid region. Quaternary Research 18, 52-71.

Sugita, S., 1993. A model of pollen source area for an entire lake surface. Quaternary Research 39 (2), 239-244.

Sugita, S., 1994. Pollen representation of vegetation in Quaternary sediments: theory and method in patchy vegetation. Journal of Ecology 82, 881-897.

Sugita, S., 2007a. Theory of quantitative reconstruction of vegetation I: pollen from large sites REVEALS regional vegetation composition. The Holocene 17 (2) 229-241.

Sugita, S., 2007b. Theory of quantitative reconstruction of vegetation II:all you need is LOVE. The Holocene 17 (2), 243-257.

Sugita, S., Gaillard, M.J., Broström, A., 1999. Landscape openness and pollen records: a simulation approach. The Holocene 9 (4), 409-421. 
Sun, X.J., Wu, Y.S., 1987. Distribution and quantity of sporopollen and algae in surface sediments of the Dianchi Lake, Yunnan province. Marine Geology \& Quaternary Geology 7 (4), 81-92 (in Chinese with English abstract).

Tauber, H., 1967. Investigations of the mode of pollen transfer in forested areas. Review of Palaeobotany Palynology 3, 277-286

Tian, F., Xu, Q.H., Li, Y.C., Cao, X.Y., Wang, X.L., Zhang, L.Y., 2008. Pollen assemblage characteristics of lakes in the monsoon fringe area of China. Chinese Science Bulletin 53 (21), 3354-3363.

Traverse, A., 1992. Organic fluvial sediment: palynomorphs and "palynodebris" in the lower Trinity River, Texas. Annals of the Missouri Botanical Garden 79 (1), $110-125$.

Vincens, A., Bonnefille, R., 1988. Modern pollen sedimentation in Africa lakes (abstract). 7th International Palynology Congress, Brisbane, pp. 173.

Wang, R.B., Su, J.F., 2008. Historic landform in central Hebei Plain and causes of formation of Baiyangdian Lake. Scientia Geographica Sinica 28 (4), 501-506 (in Chinese with English abstract).

Xu, Q.H., Chen, S.Y., Kong, Z.C., Du, N.Q., 1988. Preliminary discussion of vegetation succession and climate change since the Holocene in the Baiyangdian Lake district. Acta Phytoecologica and Geobotanica Sinica 12 (2), 143-151 (in Chinese with English abstract).
Xu, Q.H., Wu, C., Meng, L.Y., Wang, Z.H., Yang, X.L., Yao, Z.J., 1994. Alluvial pollen assemblages feature of different geomorphologic units on the North China Plain. Chinese Science Bulletin 19, 1792-1795 (in Chinese with English abstract).

Xu, Q.H., Yang, X.L., Wang, Z.H., Wu, C., Meng, L.Y., Yao, Z.J., 1995. Study on pollen transportation by rivers. Acta Botanica Sinica 37, 829-832 (in Chinese with English abstract).

Xu, Q.H., Yang, X.L., Wu, C., Meng, L.Y., Wang, Z.H., 1996. Alluvial pollen on the north China Plain. Quaternary Research 46, 270-280.

Xu, Q.H., Li, Y.C., Yang, X.L., Xiao, J.L., Liang, W.D., Peng, Y.J., 2005. Source and distribution of pollen in the surface sediment of the Daihai Lake, Inner Mongolia. Quaternary International 136 (1), 33-45.

Xu, Q.H., Li, Y.C., Zhou, L.P., Li, Y.Y., Zhang, Z.Q., Lin, F.Y., 2007. Pollen flux and vertical dispersion in coniferous and deciduous broadleaved mixed forest in the Changbai Mountains. Chinese Science Bulletin 52 (11), 1540-1544.

Zheng, Z., Huang, K.Y., Xu, Q.H., Lu, H.Y., Cheddadi, R., Luo, Y.L., Beaudouin, C., Luo, C.X., Zheng, Y.W., Li, C.H., Wei, J.H., Du, C.B., 2008. Comparison of climatic threshold of geographical distribution between dominant plants and surface pollen in China. Science in China Series D: Earth Sciences 51, 1107-1120. 